\title{
BRITISH NON-FERROUS METALS RESEARCH ASSOCIATION
}

\author{
NEW RESEARCH LABORATORIES
}

$\mathrm{O}^{\mathrm{N}}$ N May 13 Sir Alexander Fleck, chairman of Imperial Chemical Industries, Ltd., opened a new laboratory block for the British Non-Ferrous Metals Research Association at Euston Street in London. The laboratories have gradually been extending on this site since 1930 and now contain about 53,000 sq. ft. of floor space and house a staff of about 180. They serve the needs for co-operative research of practically all branches of the non-ferrous metals industry, and the $40-50$ research projects in progress cover the production, properties and uses of the commoner non-ferrous metals, certain aspects of the metallurgy of the metals concerned with nuclear energy, and metal finishing.

The new laboratory was made possible by the generous response to a building fund on the part of the Association's membership of more than 600 firms and of the Department of Scientific and Industrial Research, which has treated contributions as grant earning. The main features of the new block are a much-enlarged foundry, new corrosion and physics laboratories and a new electroplating shop. Alterations to existing buildings have enabled a new creep testing laboratory to be built which will allow the capacity to be doubled to more than 100 units, the rehousing of many different types of fatigue testing machines in one room, and the provision of more space for the General Metallurgy Section. This, among other things, gives the Section more room for vacuum apparatus for the determination of gases in metals.

In the foundry, moulds are now made in one wellequipped bay and poured in an adjacent melting and casting shop. The melting equipment consists of five gas-fired lift-out crucible furnaces, a gas-fired baleout furnace for research into die-casting problems, a $600-\mathrm{lb}$. low-frequeney induction furnace for studying the performance of refractory linings, and also an electric resistance furnace and a high-frequency furnace each capable of melting charges of up to $20 \mathrm{lb}$. of copper or nickel alloys in vacuum or special atmospheres.

From the inception of the laboratories the value of physical methods of analysis has been realized and the Association's work in developing spectrographic analysis of metals to its present state of efficiency is well known. Recently, the X-ray fluorescence method of analysis has aroused considerable interest and it appears extremely promising for analysing the major constituents in alloys and for the analysis of ores and slags. Its potentialities are being studied, using a spectrometer designed by the Physics Section and built in the Association's workshops. In the Chemistry Section emphasis is on the physico-chemical methods of analysis, including polarography, spectrophotometry and the use of the flame spectrophotometer.

The Physies Section has two X-ray diffraction sets and a variety of special-purpose cameras for crystal orientation studies, the identification of phases in compounds and other tasks. An electron diffraction camera is available for studying oxide and other thin films on metal surfaces.

Instrumentation for automatic inspection and process control is becoming increasingly important in the metal industry, and several studies are being made of problems in this field. They include the use of eddy currents for rapid inspection of tubes and rods for flaws, an investigation into emissivity variations of hot metal surfaces which affect the performance of radiation pyrometers, and the development of a novel thermo-electric gauge for measuring, non-destructively, the thickness of electrodeposits.

Research on electroplating and allied metalfinishing processes is now housed in a large new laboratory equipped both for fundamental work and for plating on a semi-industrial scale in pilot plating lines. Equipment is available for measuring the stresses during plating, for measuring cathode potentials and throwing power, and for assessing the ductility and adhesion of coatings. Exposure tests on plated specimens are carried out on the roof of the laboratories, but much work has been done on accelerated corrosion tests, including one in which the parts are exposed to a humid atmosphere containing traces of sulphur dioxide which simulates in a few hours the effects of exposing the parts to a city atmosphere for several months.

Many modern plating solutions contain organic additions which affect the smoothness, brightness and mechanical properties of the coatings in a beneficial way. Exactly how these organic agents do this is not known, and typical addition agents prepared with tracers, such as carbon-14 and sulphur-35, are being used to study the mechanism of the process.

In the Corrosion Section one laboratory is employed solely for sea-water corrosion studies, the current work being concerned mainly with the attack on heat-exchanger tubes handling heavily polluted estuarine waters in power stations, oil refineries and in ships. Some of these tests are at controlled potentials to simulate the effects of applied cathodic protection. The influence of marine atmospheres is assessed by exposure at a site on Hayling Island and the laboratory roof site is used mainly for inland tests. Stress corrosion tests are carried out at both these sites and there is also a special highhumidity room for this purpose in the corrosion laboratory.

One of the main uses of non-ferrous metals is the handling of supply waters, and the effect of water composition on the resistance to corrosion of various metals is being studied at field stations and also in the laboratories using synthesized waters.

The General Metallurgy Section, besides carrying out the usual metallographic work, heat treatment and constitutional studies, contains a metal-working shop with a 12-in. rolling mill, a 500-ton press for extrusion and forging, a small forging hammer and a drawbench. This section of the laboratories is also working on the development of titanium, zirconium and thorium alloys and has argon-are melting equipment appropriate for this type of work. Special apparatus which uses an atmosphere of argon for carrying out long-term creep tests on these reactive metals is housed in the new creep laboratory. 